\title{
ГРАМАТИЧНИЙ СТАТУС ДІЕПРИСЛІВНИКА В СИСТЕМІ ЧАСТИН МОВИ
}

У статті досліджено граматичний статус дієприслівника. Визначено, що дієприслівник як граматичний клас слів займає окрему граматичну нішу і є незмінною частиною мови віддієслівного утворення, що функціонує зі значенням процесуальної обставини або виступає граматичним центром обставинного звороту чи вставного словосполучення. Оскільки дієприслівник має своєрідну семантику, виконує специфічну, відмінну від дієслова й прислівника роль організатора своєрідних граматичних об'єднань у межах речення, його правомірно розглядати як окрему частину мови, використання якої задовольняє екстралінгвальні вимоги всіх функціональних різновидів української мови.

Ключові слова: частини мови, дієприслівник, граматичний статус, дієслівні форми, віддієслівне утворення, прислівник.

Lysak L. K. The Grammatical Status of Diiepryslivnyk in the System of Parts of Speech . The article examines the grammatical status of diiepryslivnyk (the specific adverbial form of the Ukrainian verb). It has been determined that the diiepryslivnyk as a grammatical class of words occupies a separate grammatical niche and is an unchangeable part of speech of deverbal nature, which functions with the meaning of the processual adverbial modifier or acts either as the grammatical center of an adverbial phrase or expletive structure. Ascribing the diiepryslivnyk to the verbal-adverbial or adverbial-verbal category abridges the specificity in determining its grammatical status. Diiepryslivnyk is a deverbal formation that inherits from the verb its stem with prefixes, affixes, postfix -sia, by which the meaning of the aspect is transmitted to the adverbial participle, and which has not lost its ability to have dependent words. Yet the existence of these grammatical indicators is not considered to be the basis for including the diiepryslivnyk to the deverbal forms. The difference between the diiepryslivnyk as an unchangeable form and the adverb itself is that the diiepryslivnyk expresses the meaning of a procedural adverbial modifier. The adverb is deprived of this, because it includes non-processual words. They also differ by the fact that among diiepryslivnyks there are no such words that in the isolated way, without reference to other words, would be perceived with the certain meaning of an adverbial modifier. The semantics of the adverb is clearly determined even in the isolated position.

Key words: parts of speech, diiepryslivnyk, grammatical status, verbal forms, deverbal formation, adverb.

\section{Вступ}

У сучасному східнослов'янському мовознавстві місце дієприслівника як мовного феномена визначається по-різному, хоч підходи до його граматичного статусу, за твердженням дослідників, єдині. Указується на те, що при встановленні характеристики його як граматичної одиниці враховують семантичні, морфологічні (зокрема й словотвірні), синтаксичні ознаки (Вихованець, 1982; Волох, 1989; Дорошенко, 1992; Загнітко, 1990 та ін.).

Дієприслівник традиційно кваліфікують як граматичну категорію, що поєднує в собі ознаки дієслова й прислівника. 3 огляду на це його іменують дієслівно-прислівниковим утворенням (Вихованець, Городенська \& Грищенко, 1982: 116).

У поєднанні в дієприслівнику ознак двох частин мови бачиться його своєрідність, яка жодною мірою не ставиться під сумнів. Однак, незважаючи 
на неможливість заперечити факт наявності в дієприслівнику ознак дієслова й прислівника, усе ж виникають запитання, пов'язані з його граматичним статусом, що і є метою нашої розвідки. У досягненні цієї мети передбачено здійснити таке завдання: на основі врахування специфіки лексичних, морфологічних і синтаксичних ознак дієприслівника уточнити його граматичний статус.

\section{Методи та методики дослідження}

Методи дослідження зумовлені його метою й завданням. В аналізі матеріалу застосовано описовий метод, метод компонентного аналізу, метод зіставлення.

\section{Результати та дискусії}

Традиційно дієприслівник характеризують як дієслівну форму в шкільних підручниках, у вишівських граматиках і в спеціальних дослідженнях (Волох, Чемерисов \& Чернов, 1989: 89; Кузьмич, 1996; Сасинович, 1963: 18).

Прагнення довести формальну належність дієприслівника до дієслова змушує його прихильників удаватися до надширокого тлумачення парадигми лексеми-дієслова, що й «зумовило зарахування <...> дієприслівника до дієслівної парадигматики» (Загнітко, 1990: 5). Віднесення дієприслівника до дієслівних форм, засноване на досить широкому тлумаченні дієслівної парадигми, прийнятне в шкільній граматиці, але дискусійне в науковій.

Сумніви в правомірності називати дієприслівник формою дієслова вилилися в називання дієприслівника дієслівним утворенням. В. М. Русанівський, не вилучаючи дієприслівник із розряду дієслів, дає таке пояснення «дієслівного утворення», яке має, на наш погляд, принципове значення для встановлення граматичного статусу дієприслівника. Розглядаючи інфінітив, особові форми, дієприкметник і дієприслівник, учений зауважує, що якби їх «не об'єднувала спільна семантика (всі вони є носіями динамічної ознаки) й коли б не те, що всі вони виходять із дієслівної основи, то кожне із цих дієслівних утворень можна було б назвати окремою частиною мови» (Русанівський, 1977: 41-42). Дієприслівник не виносять за межі дієслова лише за тим, що він, як і інші дієслівні утворення, є носієм динамічної ознаки, яка закладена в дієслівній основі. За всіма іншими властивостями його можна було б уважати окремою частиною мови. Не визнаючи його окремий частиномовний статус, В. М. Русанівський іменує його дієслівним утворенням. Цей термін у такому контексті набуває подвійного значення: дієприслівник - це й дієслівна одиниця, хоч і не форма; дієприслівник - це не форма, а лише утворення, що з'явилося на грунті дієслівної основи. Видається правомірним у терміні «віддієслівні утворення» вбачати саме віддієслівність створених на дієслівних основах лексем, а не форм дієслова як частини мови, що характеризується численними семантичними й граматичними ознаками, не притаманними віддієслівним утворенням, зокрема й дієприслівнику.

Якщо дієприслівник не можна кваліфікувати як форму дієслова, то чи достатньо підстав зараховувати його до прислівника? 
Ставити в таку площину питання про дієприслівник змушує той факт, що в останні десятиріччя набув поширення погляд, за яким усі частини мови поділяються на основні й супровідні. Основні - це іменник і дієслово, супровідні - прикметник і прислівник. До останнього зараховано дієприслівник. У цій класифікації неспростовним є кваліфікація іменника й дієслова основними частинами мови, адже вони становлять граматичну основу речення. Визнання за прикметником і прислівником супровідної ролі теж слід уважати справедливим, якщо спиратися на традиційний поділ слів на десять частин мови.

Однак не можна не помітити, що виокремлення чотирьох частин мови завдячує типологічному підходу до їх виявлення, що характеризується універсальністю. I хоч прибічники такого поділу слів на частини мови декларують урахування спільних синтаксичних, морфологічних і семантичних властивостей, запропонована ними універсальність усе ж заснована на перевагах одних властивостей і на неувазі до інших. Виокремлюється передусім синтаксична характеристика, з морфологічної - незмінність, а категоріально-граматичні, словотвірні й семантичні віднесені до додаткових. Порушено принцип урахування врівноваженості різних ознак, за якими визначають частини мови. Об'єднані в межах чотирьох частин мови слова потребують деталізації, оскільки не всі беззастережно можна розподілити між ними.

Якщо брати до уваги різнорідне наповнення основних частин мови, то й у них між їхніми функціональними й семантичними групами слів немає однозначності, адже, наприклад, клас присудків не відповідає класу дієслів, а клас підмета - класу іменника, як і навпаки: іменник не завжди функціонуе в ролі підмета, а деякі форми дієслова - у функції присудка. Така неоднозначність властива й іншим словам, яких не обіймають основні частини мови. Строкатість лексичного й особливо граматичного значень слів флективних мов, до яких належить українська, потребує деталізації кожного класу слів за семантичними, морфологічними, синтаксичними й словотвірними (для похідних слів) критеріями. Прийняття такого шляху в групуванні частин мови виключає можливість застосування критерію, за яким «у рамках цих чотирьох одиниць (іменників, дієслів, прикметників і прислівників. - Л. Л.) структуруються найтиповіші для граматичної системи української та інших мов частиномовні переходи» (Кузьмич, 1996: 4).

Це стосується класу слів, об'єднаних назвою «дієприслівник». Наявність у ньому властивостей, притаманних саме йому, вимагає окремого розгляду на предмет правомірності / неправомірності віднесення його до розряду прислівника.

Характерну ознаку дієприслівника становить те, що деякі супровідні дієслівні категорії впливають на формування в ньому своєрідного семантичного наповнення й функціонування як синтаксичної одиниці: він може виступати в ролі прислівника й здатний утворювати зворот, об'єднуючи навколо себе залежні слова. При цьому характерною його особливістю є те, що й у функції прислівника, і в ролі центру дієприслівникового звороту його семантичне наповнення суттєво відрізняється від прислівникового. Про це 
доводиться говорити, незважаючи на те, що дієприслівник має означальнообставинне значення, тобто, як і прислівник, указує на ознаку дії. Проте принципова відмінність їх полягає в тому, що прислівник передає статичну, а дієприслівник - динамічну ознаку. У цьому сенс їхнє розрізнення, не враховувати яке не можна. Наявність дієвості дієприслівника дозволяє йому виступати:

- у напівпредикативній функції - Я від світання до смеркання Робив, не маючи мети (Д. Павличко);

- у функції предикативної обставини - Все стерпить, хіба заплаче стиха, Дивлячись на добрих малюків (В. Симоненко).

Властивість дієприслівника передавати динамічну ознаку дії варто визнати його категоріальною прикметою. Такий висновок не суперечить загальновідомому визнанню того, що дієприслівник, як і прислівник, належить до незмінних слів. Проте треба визнати перебільшенням прагнення ототожнити дієприслівник і прислівник на основі того, що їм властива незмінність і здатність виступати в ролі обставин. Було б помилкою обмежуватися визнанням дієприслівника як незмінного граматичного елемента, який за співвіднесеністю класів слів із членами речення дорівнюється прислівнику, залишаючи поза увагою семантичний і синтаксичний критерії щодо його граматичної кваліфікації.

Ставити дієприслівники й прислівники в один ряд, спираючись лише на незмінність і обставинне функціонування, не можна, тому що за таким вузьким підходом до тієї ж самої частини мови слід зарахувати й предикативні слова, вигуки, невідмінювані іменники й прикметники. Але вони потребують диференціації, оскільки, наприклад, іменники й прикметники, на відміну від інших класів слів, поєднуються зі службовими словами. Звідси можна зробити висновок, що ігнорувати інші властивості незмінних слів значить, застосовувати надто вузькі критерії розрізнення частин мови, точніше - надавати пріоритету одному з підходів (у випадку з дієприслівником - лише незмінності), відкидаючи інші істотні морфологічні прикмети.

Визнання незмінності дієприслівника ставить його на одну площину в сприйнятті його синтаксичної ролі, схожою з прислівником: бути обставиною. Проте, застосовуючи синтаксичний підхід, не слід впадати в крайність ототожнення морфологічного класу слів і членів речення, як це припускалося в XIX ст. К. С. Аксаковим, який під одну категорію підводив прислівник як частину мови й обставину як член речення (Аксаков, 1880: 402).

Зазвичай, таке пряме ототожнення спостерігається у випадках, у яких менш за все враховуються граматичні властивості слів. Прикладами в цьому $€$ передусім прислівники й обставини, дієприслівники й обставини. Якщо для прислівника можна застосувати відому в мовознавстві універсальність - ураховувати в розподілі слів за частинами мови їхні істотні й визначальні ознаки (наприклад, ті слова, для яких істотною є функція присудка, називати дієсловами, функції підмета й додатка - іменниками, функція означення - прикметниками, функція обставини - прислівниками), то для дієприслівника вона неприйнятна. Функціонування одиничних дієприслівників 
у ролі обставини - порівняно нечастотне явище. Здебільшого дієприслівник виконує функцію центру дієприслівникового звороту, у якому дієприслівник не тотожний ролі прислівника як окремого члена, тому що значення дієприслівникового звороту не збігається зі значенням дієприслівника. До того ж і значення всього звороту з одним і тим самим дієприслівником може бути різним, що залежить від контексту, до якого входить дієприслівник. Не можна не враховувати й того, що окремі дієприслівники здатні формувати вставні словосполучення на основі здатності керувати іншими словами, виступаючи в ролі прийменників.

До того ж серед дієприслівників немає таких слів, які б ізольовано, тобто без зв'язку з іншими словами, сприймалися з певним обставинним значенням, як це засвідчується в прислівниках: тепло, тихо й радіючи, закінчивши. За здатністю мати самостійне лексичне значення прислівники, як відомо, поділяють на означальні й обставинні, які зазвичай розпадаються: означальні - на якісно-означальні, якісно-кількісні, способу дії, обставинні - на прислівники місця, часу, причини, мети (Леонова, 1983: 243). Наприклад, якісно-означальний прислівник тепло функціонує з тим самим значенням і в ролі обставини в словосполученні тепло гріє сонце, і в складі головного члена речення: Надворі було тепло. Визначити в дієприслівнику якусь певну ознаку, певне значення неможливо. До якої із груп, що виділяються в прислівнику, можна віднести дієприслівник радіючи? До жодної, оскільки в реченні: - Буде мені спокій, - промовляє радіючи (Марко Вовчок) він сприймається зі значенням обставини способу дії, а у висловленні: Biн посміхнувся, радіючи перемозі (О. Гончар) - цей дієприслівник формує зворот причинового значення.

У прислівнику, як і в дієприслівнику, немає системи флексій, завдяки яким виражаються синтаксичні відношення між членами синтагми. У цьому їхн схожість. Але відмінність у тому, що включення прислівника до складу синтагми не впливає на форму інших членів синтагми (пор.: добре працював, добре працювалось). Він не керує, а зв'язком прилягання лише приєднується до дієслова. Така його граматична природа.

Дієприслівник не такий нейтральний: він керує, тобто вимагає певної форми залежно від семантики дієслова, від якого походить, наприклад: виходячи з класу, заходячи в клас. Дієприслівник може створювати різні синтаксеми: їууи до сестри (до кого?), їдучи до Києва (куди?), їдуи з братом (з ким?), ідучи електричкою (як?). Саме ця властивість дієприслівника дозволяє утворювати словосполучення, тобто дієприслівниковий зворот, значення якого визначає присудок і контекст.

Відмінність прислівника й дієприслівника ще й у тому, що прислівник $є$ детермінантом для дієслова, прикметника. Дієприслівники до прикметника не приєднуються. Оскільки це так, то неправомірно ставити знак рівності між прислівником і дієприслівником.

Отже, у визначенні граматичного статусу будь-якого граматичного класу слів, а в нашому випадку - дієприслівника, не можна віддавати перевагу тому чи тому критерію, тобто стояти лише на суворому семантичному 
підході, чи тільки на строгих морфологічних ознаках, чи виключно на синтаксичних властивостях або словотвірних показниках. Тільки при чотириєдиному врахуванні класифікаційних ознак класів слів слід визначати статус відповідного класу слів і, відзначаючи в них властивості, притаманні іншим класам, окреслювати їхню схожість і відмінність, а відповідно - і своєрідність. При цьому важливо не випускати з поля зору того, що яким би складним і суперечливим не було функціонування граматичної категорії, вона завжди, користуючись словами О. О. Потебні, сказаними про граматичні форми, стоїть сама за себе. Ось слова вченого: «Кожна форма на своєму місці. Кожна відповідає певним вимогам думки мовця, якщо передбачити в ньому знання своєї мови» (Потебня, 1941: 111). Саме з усвідомлення своєрідності кожного граматичного класу слів треба виходити у визначенні граматичного статусу дієприслівника. Усе викладене змушує стверджувати, що дієприслівник як граматичний клас слів займає окрему граматичну нішу.

\section{Висновки}

На користь визначення дієприслівника як окремої частини мови називаються такі ознаки дієприслівника.

Дієприслівник - віддієслівне утворення, що успадкувало від дієслова основу з префіксами, афіксами, постфіксом -ся, завдяки яким до дієприслівника переноситься значення видів, і яке не втратило здатності мати залежні слова. I все ж наявність цих граматичних показників не визнається підставою для зарахування дієприслівника до переліку дієслівних форм. Дієприслівнику не властива категорія граматичного часу: дериваційні суфікси -ачи, -учи та - ши не пов'язані з розрізненням граматичного часу. 3 участю дієприслівника передається часове значення попередності, одночасності, наступності, але тільки у відповідному контексті. Відносний час не граматична категорія. Дериваційні суфікси -ачи, -учи та -ши не пов'язані з протиставленням видів: розрізнення видів перенесено до дієприслівника з дієслівною основою, у складі якої є відповідні афікси. Названі дієслівні ознаки не мають граматичних показників їх розрізнення. Вони закладені в дієслівній основі, принесли в дієприслівник те, що визначає дієслово як частину мови - вираження дії процесуальності. Тому вважати ці суфікси словозмінними немає достатніх підстав. Специфіка цих суфіксів у тому, що вони утворили незмінні віддієслівні форми, які в реченні виконують функцію обставин у випадку одиничного їхнього вживання або стають граматичним центром утворення дієприслівникового звороту чи вставного словосполучення.

Однак ні те, що дієприслівник $є$ незмінною формою, ні те, що він функціонує з обставинним значенням, що робить його подібним до прислівника, не є підгрунтям для кваліфікації його як прислівника. Відмінність дієприслівника як незмінної форми від прислівника в тому, що дієприслівник передає процесуальне обставинне значення. Прислівник позбавлений цього, оскільки включає не процесуальні слова. Не схожі вони й тим, що серед дієприслівників немає таких слів, які б ізольовано, без зв'язку з іншими словами, сприймалися з певним обставинним значенням. Семантика ж 
прислівника чітко визначена й у ізольованому стані. Крім цього, є значна кількість дієприслівників, які не можуть функціонувати одинично: вони можливі лише в єдності із залежними словами. I, нарешті, те, що дієприслівник має здатність керувати іншими словами, у той час як прислівник не володіє такою властивістю. Отже, дієприслівник - незмінна частина мови віддієслівного утворення, що функціонує зі значенням процесуальної обставини або виступає граматичним центром обставинного звороту чи вставного словосполучення.

Такими є докази щодо надання дієприслівнику статусу окремої частини мови. Таке розуміння граматичної сутності дієприслівника покладено в основу встановлення ролі одиничних дієприслівників як прислівників і функціонування утворених на основі дієприслівника дієприслівникових і вставних зворотів.

Результати дослідження є вагомою основою для подальшої розробки підходів до розв’язання окресленої проблеми.

\section{ЛIТЕРАТУРА}

1. Аксаков К. С. Полное собрание сочинений. Москва: М. Тип. университет, 1880. Т. 3. Ч. 2. 470 с. 2. Вихованець І. Р., Городенська К. Г., Грищенко А. П. Граматика української мови. Київ: Радянська школа, 1982. 208 с. 3. Волох О. Т., Чемерисов М. Т., Чернов Є. І. Сучасна українська літературна мова: Морфологія. Синтаксис. Київ: Вища школа, 1989. 334 с. 4. Дорошенко С. І. До питання про граматичний статус дієприслівника. Лінгвістичні дослідження: Збір. наук. праць. Харків, 1992. Вип. 2. С. 13-17. 5. Загнітко А. П. Дієслівні категорії в синтагматиці і парадигматиці. Донецьк: ДонНУ, 1990. 132 с. 6. Камынина А. А. Современный русский язык: Синтаксис простого предложения. Москва: МГУ, 1983. 102 с. 7. Кузьмич О. М. Віддієслівні утворення в українській мові: автореф. дис. ... канд. філол. наук: 10.02.01. Київ, 1996. 16 с. 8. Леонова М. В. Сучасна українська літературна мова: Морфологія. Київ: Вища школа, 1983. 264 с. 9. Олексенко О. А. Дієприслівник у проекції категорії стану. Лінгвістичні дослідження. 2017. Вип. 46. С. 80-85. 10. Потебня А. А. Из записок по русской грамматике. Москва: АН СССР, 1941. Т. 4. 406 с. 11. Русанівський В. М. Дієслово - рух, дія, образ. Київ: Радянська школа, 1977. 110 с. 12. Сасинович Е. С. Дієприслівник у сучасній українській мові. Київ: Радянська школа, 1963. 103 с.

\section{REFERENCES}

1. Aksakov, K. S. (1880). Polnoe sobranye sochynenyi [The collected works].(Vol. 3. Part 2). Moskva: M. typ. Universytet [in Russian]. 2. Vykhovanets, I. R., Horodenska, K. G., \& Hryshchenko, A. P. (1982). Hramatyka ukrainskoi movy [Grammar of the Ukrainian language]. Kyiv: Radianska shkola [in Ukrainian]. 3. Voloh, O. T., Chemerysov, M. T., \&Chernov, Ye. I. (1989). Suchasna ukrainska literaturna mova: Morfolohiia. Syntaksys [Modern Ukrainian literary language: Morphology. Syntax]. Kyiv: Vyshcha shkola [in Ukrainian]. 4. Doroshenko, S. I. (1992). Do pytannia pro hramatychnyi status diiepryslivnyka [To the issue of the grammatical status of the participialad verb]. Lingvistichni doslidzhennja - Linguistic Research, 2, 13-17 [in Ukrainian]. 5. Zagnitko, A. P. (1990). Diieslivni katehorii v syntahmatytsi i paradyhmatytsi [Verbal categories in syntagmatics and paradigmatics]. Donetsk: DonNU [in Ukrainian]. 6. Kamynina, A. A. (1983). Sovremennyi russkii yazyk: Sintaksis prostoho predlozheniia [Modern Russian language: Syntax of the simple sentence]. Moskva: MGU [in Russian]. 7. Kuzmych, O. M. (1996). Viddiieslivni utvorennia v ukrainskii movi [Verbal Structures in the Ukrainian 
language]. Extended abstract of candidate's thesis: Kyiv [in Ukrainian]. 8. Leonova, M. V. (1983). Suchasna ukrainska literaturna mova: Morfologiia [Modern Ukrainian literary language: Morfologiia]. Kyiv: Vyshcha shkola [in Ukrainian]. 9. Oleksenko, O. A. (2017). Diiepryslivnyk u proektsii katehorii stanu [Participial adverb in the projection of the category of state]. Lingvistichni doslidzhennja - Linguistic Research, 46, 80-85. Retrieved from http:// doi.org/10.5281/zenodo.1048732 [in Ukrainian]. 10. Potebnya, A. A. (1941). Yz zapysok po russkoi hrammatyke [From the notes on Russian grammar]. (Vol.4). Moskva: AN SSSR [in Russian]. 11. Rusanivskyi, V. M. (1977). Diieslovo - ruh, diia, obraz[Verb-movement, action, image]. Kyiv: Radianska shkola [in Ukrainian]. 12. Sasynovych, E. S. (1963). Diiepryslivnyk u suchasnii ukrainskiy movi [Participial adverbinthe modern Ukrainian language]. Kyiv: Radianska shkola [in Ukrainian].

Лисак Лариса Костянтинівна - кандидат філологічних наук, доцент, завідувач кафедри гуманітарної підготовки, Донбаська національна академія будівництва і архітектури; вул. Героїв Небесної Сотні, 14, Краматорськ, Донецька обл., 84333, Україна.

Tel.: +38-050-230-02-57

E-mail: lklysak@ukr.net

https://orcid.org/0000-0003-3029-0320

Lysak Larysa Kostiantynivna - PhD in Philology, Associate Professor, Head of the Department of Humanitarian Training, Donbas National Academy of Civil Engineering and Architectur; Heroiv Nebesnoi Sotni Str., 14, Kramatorsk, Donetsk region, 84333, Ukraine.

Надійшла до редакції 01 березня 2019 року 